\title{
Transnacionālās organizētās noziedzīgās grupas starptautisko kriminālo tīkla struktūru kontekstā
}

\author{
Dr. iur. Andrejs Vilks \\ Rīgas Stradiña universitāte, Juridiskā fakultāte, \\ Tiesību zinātñu katedra, Latvija \\ andrejs.vilks@rsu.lv
}

\section{Kopsavilkums}

Mūsdienu sabiedrības izteikto globalizācijas procesu ietekmē ir vērojama ne tikai strauja moderno tehnoloǵiju attīstība, komunikatīvo sistēmu sfēru paplašināšanās, informācijas kā kapitāla lomas pieaugums, brīva un masveidīga cilvēku pārvietošanās pāri robežām un kontinentiem, bet arī sociāli nelabvēlīgo parādību eskalācija: pieaug terorisma akti un to draudi, ierastas kḷūst hibrīdkara elementu izpausmes, nostiprinās transnacionālās organizētās noziedzīgās grupas, kuras veido un efektīvi izmanto starptautiskās kriminālā tīkla struktūras.

Atslēgvārdi: globalizācija, kriminologiskā izziṇa, starptautiskā noziedzība, starptautiskie kriminālie tīkli, transnacionālās organizētās grupas.

Eiropas Padomes Komisija 2014. oktobrī publicēja ziṇojumu par transnacionālo organizēto noziedzību (White Paper on Transnational Organised Crime) [1]. Ziṇojumā ("Baltajā grāmatā") tika atzīts, ka pašlaik transnacionālo organizēto noziedzīgo grupu darbības jomu paplašināšanos nosaka trīs būtiskākie faktori. Pirmais no tiem ir nelikumīgo preču un cilvēku tirdzniecības mobilitāte. Agrāk nelikumīgie darījumi bija saistīti galvenokārt ar nekustamo īpašumu (lauksaimnieciskiem produktiem, valsts sektora būvniecības līgumiem u. c.), bet pēdējos gados organizētās noziedzīgās grupas ir vairāk pievērsušās kustamā īpašuma pārvietošanai un atbilstīgiem darījumiem - ieroču, narkotisko vielu, zagta autotransporta, metālu, akcīzes preču, preču ar viltotām preču zīmēm tirdzniecībai un indīgu atkritumu uzglabāšanai. Aizvien lielāku vietu organizēto transnacionālo kriminālo grupējumu darbībā ieṇem cilvēku tirdzniecība un nelegālās migrācijas kanālu izveide un to darbības nodrošināšana. 2014. gada novembrī Walk Free publicētajā ziṇojumā [2] atzīts, ka pasaulē patlaban ir 36 miljoni vergu (cilvēku 
tirdzniecības upuru), kas ir 0,5\% zemes iedzīvotāju. Pēdējā gada laikā cilvēku tirdzniecības upuru skaits ir pieaudzis par piektdaḷu vai $20 \%$. Nav šaubu, ka 2015. gadā vergu un cilvēku tirdzniecības upuru skaits būs pieaudzis ne mazāk strauji, ṇemot vērā nelegālo migrantu neizsīkstošās plūsmas no Ziemeḷāfrikas uz Eiropu.

Otrais faktors ir institucionālie un politiskie notikumi pasaulē. Tas sevī ietver valstu tradicionālo robežu atcelšanu un bezvīzu režìma ieviešanu. Izteikts piemērs ir Eiropas Savienības un Šengenas līguma valstis. Mūsdienās praktiski nav iespējams noteikt cilvēka pārvietošanās maršrutus Eiropas Savienībā, preču, kapitāla un pakalpojumu tīklus. Šìs mūsdienu sabiedrības priekšrocības efektīvi izmanto organizētās transnacionālās kriminālās struktūras. Sabiedrība ir atgriezusies 19. gadsimta nogales apstākḷ̆os, jo vēl 1893. gadā tiesību zinātnieks Francis fon Lists atzina, ka "mēs dzīvojam laikmetā, kad profesionāls zaglis vai krāpnieks jūtas kā mājās gan Parīzē, gan Vīnē vai Londonā, kad viltota nauda tiek drukāta Francijā vai Anglijā un pēc tam tiek pārvesta uz Vāciju, kad noziedznieku grupas ilgu laiku darbojas vairākās valstīs vienlaikus".

Trešais faktors ir moderno tehnologiju attīstība, kas tika atzìta par nozīmīgāko apstākli minētajā kontekstā. Pašreiz ir iespējama zibensātra komunikācija ar jebkuru sociālu struktūru jebkurā vietā uz zemes, veicot darījumus, nodrošinot finansiālo resursu cirkulāciju, legalizējot noziedzīgi iegūtos finanšu līdzekḷus. Jaunās modernās tehnologijas aizvien plašāk tiek izmantotas arī narkobiznesā. Aizvien biežāk narkotisko vielu realizācijā tiek izmantots internets. Tīmeklī ir pieejama ne tikai informācija, kā var izgatavot psihoaktīvās vielas, to ietekme, cenas, bet arī adreses, kur šìs jau lietošanai gatavās vielas iegādāties mazumā vai vairumā.

Viena no uzskatāmākajām interneta izmantošanas iespējām narkotiku realizācijā ir saistīta ar vietni Silk Road ("Zīda celšs"), kuru tiešsaistes režìmā sāka izmantot 2011. gada februārī. Apkopotā informācija liecināja, ka, izmantojot interneta vietni, ir pārdots viens kilograms heroina, pieci kilogrami kokaīna, puskilograms metamfetamīna un 10 grami LSD. Kopējais ienākums no narkotisko vielu tirdzniecības bija 1,2 miljardi ASV dolāru. Nākotnē narkotisko vielu ieguvē varētu tikt izmantoti 3D printeri [3]. Tad pietiekami apgrūtināto un riskanto narkotisko vielu iegādi pie dīleriem varēs aizstāt psihoaktīvās vielas ieguve mājās - atpūtas telpās, virtuvē vai guḷamistabā.

2013. gadā Austrālijas valdības speciālajā ziṇojumā tika minēts, ka transnacionālo organizēto kriminālo grupējumu ienākumi gada laikā ir tikpat lieli kā dažu lielā divdesmitnieka valstu ekonomiskie apjomi [4]. Pēc Austrālijas kriminologu slēdziena kriminālo grupējumu ienākumi ir saistīti ar pasaules finansiālo krīzi, jo tie šajā procesā ātri saskatīja jaunas iespējas gūt pel̦nu. Pēc The Jakarta Globe atzinuma noziedzịgie grupējumi gada laikā nopelna vairāk nekā 870 miljardus ASV dolāru, kas ir vairāk nekā Indonēzijas iekšzemes kopprodukts. Iespējams, ka grūti būtu apzināt transnacionālo kriminālo grupējumu pel̦nu, kura ir gūta, piemēram, desmitgades laikā. Narkotisko vielu ražotājiem nākotnē būs nepieciešams jaunās paaudzes 3D (vai pat 4D) printeris, jauna programmatūra un speciāli kārtridži. Jauno narkotisko vielu ieguve varētu līdzināties kafijas tases pagatavošanai kafijas automātā. 
2013. gada novembrī Eiropola publicētajā ziņojumā par stāvokli organizētās noziedzības jomā tiek atzìts, ka ir identificētas aptuveni 3600 organizēto noziedzīgo grupu, kas aktīi darbojas Eiropas Savienībā [5]. Eiropols pēc ES Smago un organizēto noziedzības draudu novērtējuma (SOCTA) konstatē, ka aktīvākā organizēto noziedzīgo grupu darbības joma ir starptautiskā narkotiku tirdzniecība, kas ir saistīta ar pašreizējo ekonomisko krīzi un interneta pakalpojumu straujo attīstību. Šie jaunie procesi transformē organizētās noziedzības tradicionālo vērtējumu, reducējot to uz unificētu modeli, kas ir balstīts nevis uz grupu etnisko vai nacionālo sastāvu, reǵionālo piederību, bet gan uz tīkla struktūru izveidi. Tās spēj efektīvi darboties transnacionālajā vidē, sadarbojoties ar vairākiem partneriem vienlaikus dažādās kriminālo aktivitāšu jomās un dažādās valstīs un kontinentos. Organizēto transnacionālo kriminālo grupējumu tradicionālā piramīdveida struktūra ir pārveidojusies par tīklveida modeli ar mainīgiem partneriem un dažādu to dislokāciju. Šāda pieeja l̦auj koncentrēties uz maksimālu peḷnu un samazināt risku.

Kriminālie grupējumi no visas pasaules aizvien vairāk koncentrējas Eiropā, lai îstenotu savu darbību nelegālajā un legālajā jomā. Eiropas valstīs tiek ievestas narkotikas no to kultivēšanas reğioniem (piemēram, kokaīns no Dienvidamerikas, opijs un heroīns no Afganistānas), veikta organizēta nelegālā migrācija un cilvēku tirdzniecība un arī legalizēti noziedzīgā ceḷā gūtie līdzekḷi. Tiek atzīts, ka kriminālo struktūru pārstāvji iepērk nekustamos īpašumus, kuru vērtība pašreiz ir samazinājusies, iegādājas restorānus, veikalus u. c. Noziedzīgie līdzekḷi tiek ieguldìti arī spēḷu biznesā, apdrošināšanā, kur kontroles sistēmas nav tik stingras kā finanšu iestādēs un kredītiestādēs. Krievijas kriminālo struktūru pārstāvji līdzekḷus iegulda ne tikai nekustamajā ìpašumā, bet arī autouzṇēmumos, privātajās apsardzes struktūrās un seksuālo pakalpojumu iestādēs Somijā [6].

Kriminālo grupējumu pārstāvji no Kīnas īpaši aktīvi ir Francijā, kur līdzekḷus iegulda nekustamajos īpašumos, vairumtirdzniecības un mazumtirdzniecības uzñēmumos. Itālijas mafijas pārstāvjus piesaista Vācija, kur līdzekḷi tiek ieguldīti apgeērbu veikalu iegādē, celtniecības firmās un restorānu biznesā.

Pēc speciālistu atzinumiem Itālijas mafija kopā ar Krievijas, Kīnas un Gruzijas kriminālajiem sindikātiem tikai ar kontrabandu vien pelna vairāk nekā 19 miljardus eiro gadā.

Latvijā 2014. gada 3. jūnijā Ministru kabinetā tika apstiprināts Organizētās noziedzības novēršanas un apkarošanas plāns 2014.-2016. gadam [7]. Tajā ietverti uzdevumi un pasākumi, kuru mērḳis ir padarìt efektīvāku ar organizēto noziedzību saistìto noziedzịgo nodarījumu novēršanu un apkarošanu un radīt pilnvērtīgus apstākḷus tiesību aizsardzības iestāžu cinnai ar organizēto noziedzību. Plāna informatīvajā daḷā tiek uzsvērts, ka "organizētās noziedzības darbības ìstenošanu būtiski sekmē dažādu veidu resursu (finanšu, materiāltehnisko, informācijas, cilvēku u. c.) pieejamība un tiesību aizsardzības iestāžu darba specifikas pārzināšana (piemēram, atsevišķu grupu dalībnieki izmanto arī bijušo tiesību aizsardzības iestāžu darbinieku atbalstu (taktiku un metodiku), lai izvairìtos no atbildības un neitralizētu policijas veiktos operatīvos pasākumus), kā arī mijiedarbība ar citām organizētām grupām atsevišḳu noziedzīgās darbības jautājumu risināšanā uz vienlīdzības principa un savstarpēji izdevīga ekonomiskā pamata”. 
2013. gadā Valsts policijas Galvenās Kriminālpolicijas pārvaldes Organizēto noziegumu apkarošanas pārvalde pārtrauca 48 noziedzīgo grupu darbību [7]. Šie pārvaldes gūtie rezultāti ir salīdzinoši augstāki nekā 2012. gada rādītāii (sk. 1. tab.).

1. tabula. Valsts policijas pārtrauktā organizēto noziedzīgo grupu darbība 2012.-2013. gadā (absolūtajos rādītājos)

\begin{tabular}{|c|c|c|}
\hline Organizēto noziedzīgo grupu pārtrauktā darbība & 2012 & 2013 \\
\hline Narkotisko un psihotropo vielu nelegālā aprite & 32 & 31 \\
\hline $\begin{array}{l}\text { Cilvēku tirdzniecība, personu nosūtīšana seksuālai izmantošanai, } \\
\text { sutenerisms }\end{array}$ & 6 & 11 \\
\hline Šaujamieroču nelegālā aprite & 2 & - \\
\hline Zādzības & - & 2 \\
\hline Akcīzes preču nelegālā aprite: & 2 & 2 \\
\hline - naftas produktu nelegālā aprite & 1 & - \\
\hline - cigarešu nelegālā aprite & 1 & 2 \\
\hline Izspiešanas & 1 & 2 \\
\hline Kopā & 43 & 48 \\
\hline
\end{tabular}

Jāatzīst, ka transnacionālo kriminālo struktūru darbība Latvijā ir pietiekami aktīva un universāla. Tikai 2015. gada pirmajā pusgadā Valsts policija ir pārtraukusi vairāk nekā 25 organizēto kriminālo grupējumu darbību [8]. Šo grupējumu specializācija ir saistīta ar narkotisko vielu nelegālu transportēšanu un realizāciju, akcīzes preču kontrabandu, krāpšanu un parādu izspiešanu. Kriminālpolicija atzīst, ka šo grupu darbība ir daudzprofila un ir īpaši aktīva vietās, kur var gūt lielākus ienākumus. Pēdējā laikā intensīva kḷuvusi organizēto grupu darbība, nelegāli pārvietojot pāri robežai migrantus, un šajās darbībās tiek iesaistīti arī valsts pierobežas iedzīvotāji. Grupu lìderiem un dalībniekiem ir izveidoti kontakti ar kriminālajām autoritātēm, kuras no bijušajām padomju republikām ir pārcēlušās uz dzīvi Eiropas valstīs, tādējādi izveidojot plašas un nopietnas transnacionālas struktūras.

Organizētajām kriminālajām struktūrām ir raksturīgi pielāgoties mainīgajiem sociālajiem, ekonomiskajiem, politiskajiem un tiesiskajiem apstākḷiem. Vēl vairāk - tās ir centušās maksimāli izmantot transformācijas posmus un sabiedrības krīzes periodus atbilstīgu struktūru interesēs. Nacionālajiem veidojumiem integrējoties starptautiskās politiskās, ekonomiskās un finansiālās struktūrās, attīstoties daudzveidīgiem sakariem, kriminālie formējumi ieguva transnacionālu raksturu. Vienlaikus nostiprinājās šo formējumu saikne ar vietējām regiionālajām administratīvajām un ekonomiski finansiālajām struktūrām.

Noziedzīgie tīkli kriminoloǵiskajā izziṇā tiek definēti kā kopas dalībnieki, kas ir savienoti ar saitēm, kas ir veidotas dažnedažādā veidā vai arī virzìtas uz citu struktūru vai dalïbnieku atbalstu [9]. 
Atbilstīgi globālajiem ekonomiskajiem, sociālajiem un tehnologiskajiem procesiem modificējas arī organizēto kriminālo formējumu veidojumi un moduḷi. ASV tīkla struktūru pētnieki J. Arquilla, D. Ronfeldt un M. Zanini ir atzinuši [10], ka sabiedrībā funkcionē četras visplašāk izplatītās tīklu struktūras:

1) hierarhiskās struktūras, kurās ir valdošais vertikālās vadības princips (sk. 1. att.);

2) lineārās jeb ḳēdes tīkla struktūras, kurās informācija un pārvaldes uzdevumi tiek novadìti caur atsevišşiem ḳēdes elementiem (sk. 2. att.);

3) assveida tīkla struktūras, kurās sistēmas elementi ir saistìti ar centrālo posmu, kurš dažos gadỉjumos var būt lielākas sistēmas elements. Šādā modelī var būt ietvertas atsevišku struktūru specializācijas, teritoriālā "apkalpošana" vai kontrole (sk. 3. att.);

4) multisistēmiskās (hibrīdās, daudzpakāpju) tīkla struktūras. Tās var būt dislocētas dažādos reǵionos (kontinentos) ar noteiktu specializāciju vai darboties universāli.

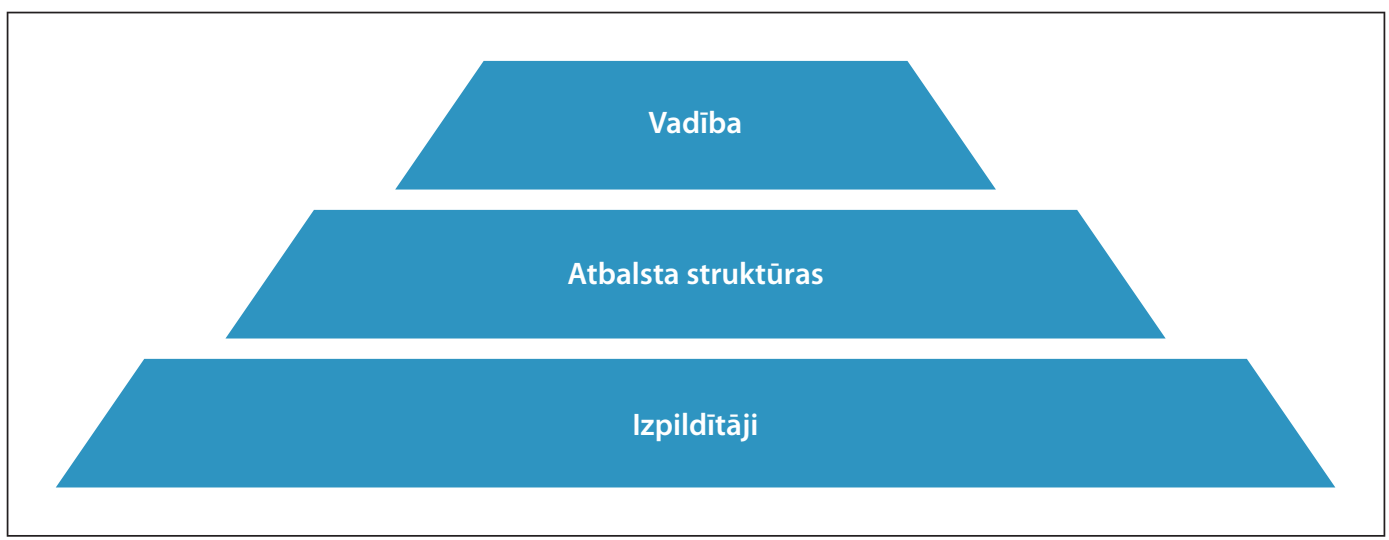

1. attēls. Hierarhiskā tīklu struktūra

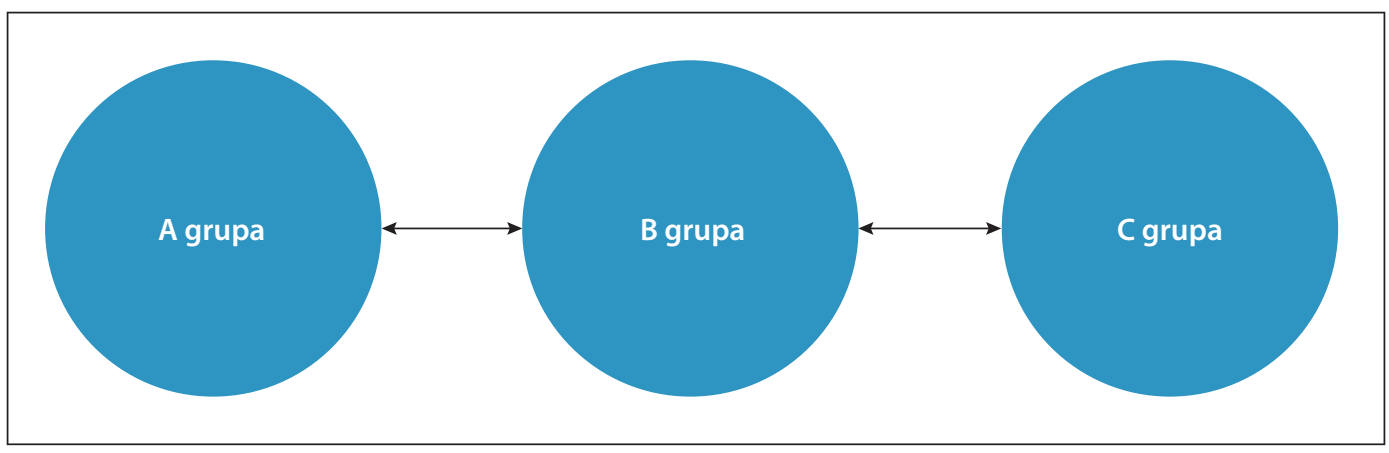

2. attēls. Lineārās jeb ḳēdes tīkla struktūras 
Andrejs Vilks. Transnacionālās organizētās noziedzīgās grupas starptautisko kriminālo tīkla struktūru kontekstā

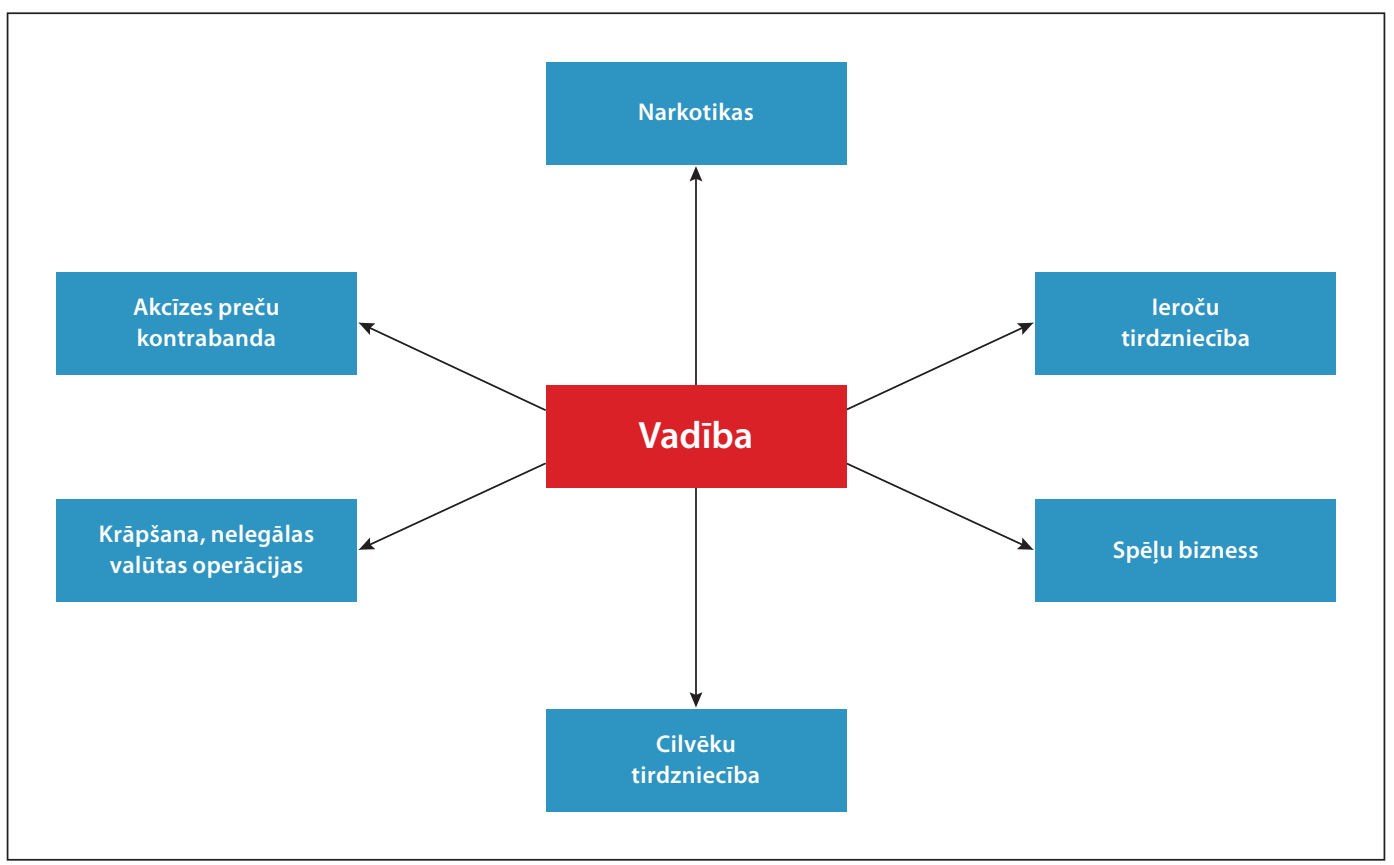

3. attēls. Assveida tīkla struktūras

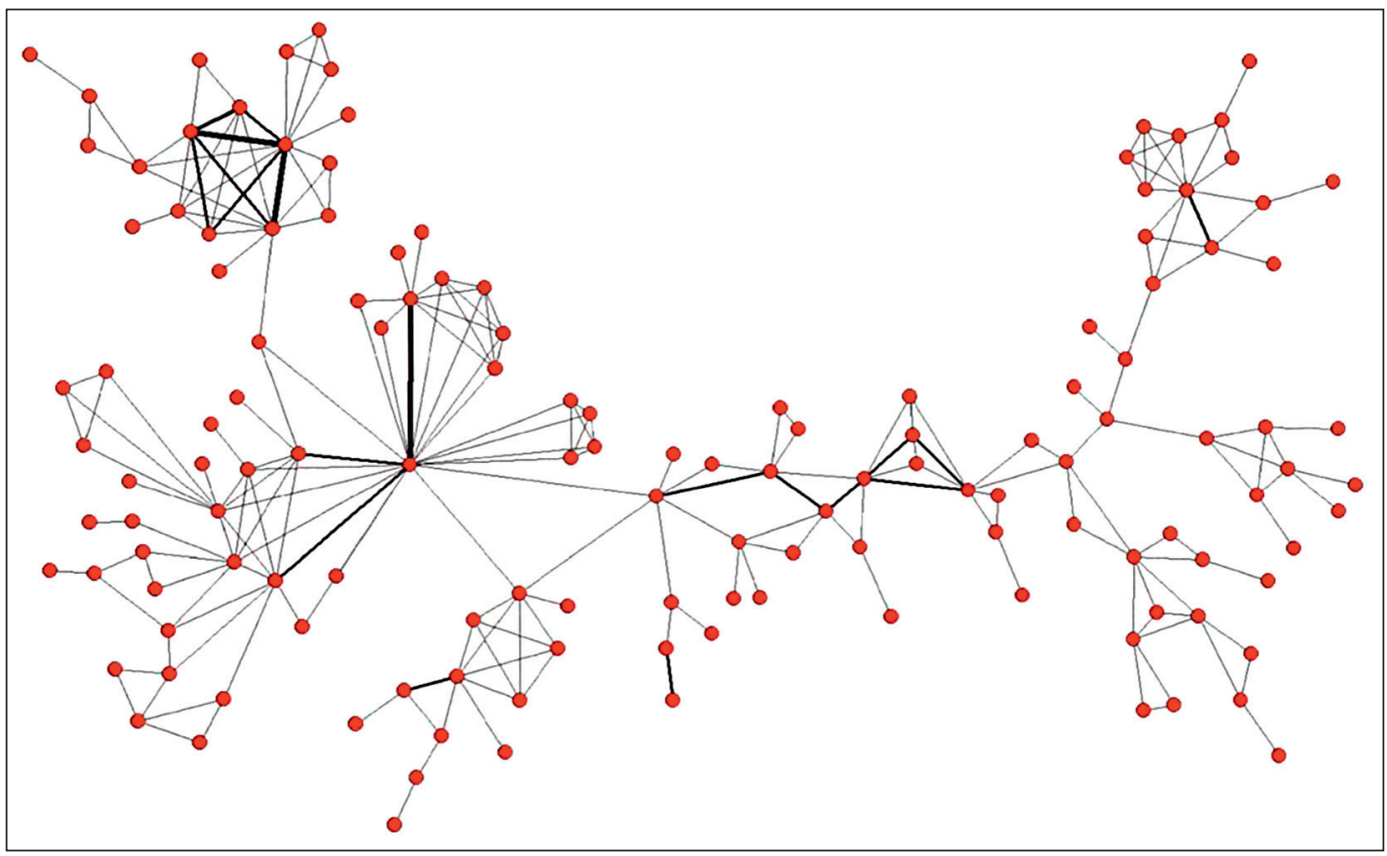

4. attēls. Multisistēmiskās (hibrīdās, daudzpakāpju) tīkla struktūras 
Tīkla struktūrām, tostarp krimināliem organizētiem veidojumiem, ir raksturīga pašorganizācija - tās var darboties autonomi, pildot agrāk noteiktos noziedzīgos uzdevumus. Tīkla struktūrās var būt iesaistīti posmi (izpildītāji, grupas), kuras var neapzināties savas darbības kriminālo raksturu (piemēram, kibernoziegumu izdarīšanas gadỉjumos). Tīkla struktūras ir tendētas maksimāli palielināt savas darbības segmentus un jomas, tādējādi iegūstot maksimālus ienākumus un palielinot savas darbības efektivitāti.

Pēdējos gados aizvien plašākas tīkla struktūras veido un tajās aktīvi darbojas teroristiskās organizācijas. Tieši tāpēc, ka teroristiskās grupas vienlaikus dislocējas un darbojas vairākās valstīs, pastāvīgi pārvietojas, izmanto modernas un jaudīgas sakaru sistēmas, to veiktie teroristiskie uzbrukumi kḷūst aizvien smagāki - ar lielāku upuru skaitu. Pētījuma rezultāti, kuri tika gūti 2014. gadā, veicot izpēti Austrālijas Pasaules ekonomikas institūtā, liecina, ka cilvēku skaits, kuri ir gājuši bojā teroristiskos aktos, no 3361 upura 2000. gadā pieaudzis līdz 17958 upuriem 2013. gadā [11]. Bojā gājušo skaits 2013. gadā, salīdzinot ar 2012. gadu, palielinājies par 60 procentiem. Pētìjuma rezultāti atklāj, ka lielākā daḷa bojā gājušo ir no Sīrijas, kā arī no Irākas, Afganistānas, Pakistānas un Nigērijas. Jāuzsver, ka no Nigērijas ir aptuveni 80\% terorisma upuru. Atbildību par teroristiskajiem aktiem uzṇēmās teroristu grupējumi "Islāma valsts" jeb Daech, Taliban, Boko haram un Al Qida. Pēc minētā institūta aprēḳiniem, izskaitḷojot globālo terorisma indeksu (Global Terrorism Index), 2014. gadā zaudējumi no teroristiskajiem aktiem sasniedza 52,9 miljardus ASV dolāru. Neapšaubāmi, rodas jautājums, kur teroristiskās organizācijas, tostarp Daech, gūst tik lielus ienākumus, lai izveidotu tīkla struktūras visā pasaulē. Minētā teroristiskā organizācija ir okupējusi Irākas teritoriju, kur ir naftas atradne, kā arī izmanto 60\% Sīrijas teritorijas, kur atrodas naftas ieguves urbumi [12]. Pēc speciālistu atzinumiem tas ienes 1,5-3,6 miljonus ASV dolāru dienā, bet gada laikā ienākumi pārsniedz 800 miljardus ASV dolāru. Ārvalstu investori no Katāras, Kuveitas, Saūda Arābijas ziedo Daech aptuveni 40 miljardus ASV dolāru. Daech ir noziedzịga organizācija pēc savas būtības, jo no iedzīvotājiem, kuri dzīvo organizācijas kontrolētajās teritorijās, ievāc aptuveni 10\% no visiem darījumiem, uzṇēmējdarbības un citām aktivitātēm. Aptuveni 20 miljardus ASV dolāru tā gūst, saṇemot izpirkumus par nolaupitajiem cilvēkiem.

Teroristisko organizāciju darbība ir l̦oti plaša, un tā pēctecīgi attīstās. 2004. gada 24. augustā tika uzspridzinātas divas Krievijas lidmašīnas. Teroristi pašnāvnieki uzspridzināja lidmašinnu TU-134A-3, kura lidoja no Maskavas uz Volgogradu, kā arī lidmašīnu TU-154B-2, kura devās no Maskavas uz Sočiem. Atbildību par lidmašīnu un cilvēku iznīcināšanu uzṇēmās Šamils Basajevs. Arī 2004. gadā tika uzspridzināta Francijas lidmašīna, kura lidoja no Šarmelšeihas. Atbildību par teroristisko aktu uzṇēmās Jemenas islāmistu grupa.

2015. gada 31. oktobrī tika uzspridzināta Krievijas pasažieru lidmašīna A321, kura lidoja no Šarmelšeihas uz Sanktpēterburgu. Bojā gāja 224 cilvēki. Minēto teroristisko aktu uzṇēmās teroristiskā organizācija Daech. 
Neapšaubāmi, smagākais un arī viens no trağiskākajiem teroristiskajiem aktiem notika 2015. gada 20. novembrī Parīzē, kur dzīvību zaudēja 129 cilvēki, bet ievainoti tika vairāk nekā 300 parīziešu un pilsētas viesu. Par galveno aizdomās turamo personu tiek uzskatīts 27 gadus vecais marokāṇu izcelsmes Beḷgijas pilsonis Abdelhamids Abauds, kurš netraucēti pārvietojās no Sīrijas uz Briseli un Parīzi, izveidoja teroristisko grupējumu un finansiāli nodrošināja tã darbību. Lielākā dạ̣a šīs teroristiskās organizācijas dalībnieku nav aizturēti, un viṇu darbība var turpināties jebkurā Eiropas pilsētā.

Kriminālajām tīkla struktūrām, salīdzinot ar tradicionālajām noziedzīgajām grupām, ir virkne priekšrocību. Tīkla struktūras pārvar geogrāfiskās un juridiskās robežas. Tās izteikti elastīgi un racionāli reageè uz iespējām un problēmām, ko rada globalizācija.

Spēja sadarboties ar citām struktūrām ārvalstīs ḷauj darboties legālajos un nelegālajos tirgos, kur peḷna ir vislielākā un vienlaikus ir minimizēti kriminālās darbības riski. Arī dažnedažādi sociālie un komunikatīvie tīkli būtiski palielina materiālo un intelektuālo kapitālu, nodrošinot piekḷuvi cilvēkiem ar īpašiem resursiem. Tīkli dod iespējas nodrošināt būtisku pienākumu un darba dalīšanu starp tīkla dalībniekiem.

Tīkla struktūrās tiek fiksētas šādas tīkla dalībnieku lomas:

- organizatori (vadība), kas nodrošina struktūru pārvaldību un to darbības atbalstu;

- drošības speciālisti, kas veic visu tīklā iesaistīto grupu un to dalībnieku, it īpaši organizatoru, drošības nodrošināšanu un aizsardzību pret apdraudējumiem;

- komunikatori - indivīdi, kuri nodrošina, lai informatīvās plūsmas efektīvi tiek novadītas no vienas struktūras uz otru vai arī visam tīklam kopumā. Viṇu pienākums ir nodot uzdevumus, informēt par situāciju un nodrošināt atgriezenisko saiti;

- vervētāji, kuru uzdevums ir paplašināt tìklu, pieņemot darbā jaunus dalībniekus, kā arī, vienojoties ar citiem tīkliem, veicināt pārbēdzēju iesaistī̌̌anos tìkla aktivitātēs. Vervētāji izmanto šādas darbības metodes: uzpirkšanu, pien̦emšanu piespiedu darbā, draudus, šantāžu, kā arī stimulēšanu.

\section{Daži virzieni transnacionālo organizēto kriminālo grupējumu pretdarbībai}

Eksperti atzīst, ka ir nepieciešama specializētu informatīvi analītisku struktūru izveide un to darbības nodrošināšana, lai tās spētu identificēt organizēto kriminālo grupējumu darbību, atklātu, novērstu un pārtrauktu to noziedzīgās aktivitātes. Ir iespējams arī plašāk un mērḳtiecīgāk izmantot starptautisko organizāciju datu bāzes (Interpola, Eiropola, Eirojust u. c.).

Būtiski ir apzināt ne tikai kaitējumu un zaudējumus, kuri rodas organizēto kriminālo grupējumu darbības rezultātā, bet arī transnacionālā līmenī, izpētot šo grupu starptautiskās darbības jomas, sadarbības partnerus, visus tīkla struktūrās iesaistītos 
elementus. Nepieciešams intensīvāk izmantot moderno tehnologiju iespējas un resursus. Šo grupu darbības izpētē ir iespējams izmantot unificētus operatīvi taktiskos uzdevumus. Modernās programmas dod iespējas ne tikai sekmīgi noteikt tīkla struktūru dalībniekus, apzināt to veiktās aktivitātes, bet arī paredzēt atbilstīgu darbību veikšanu nākotnē.

Lai izzinātu transnacionālo organizēto kriminālo grupējumu darbības jomu, ir nepieciešama sadarbība ne tikai ar Eiropas Savienības valstīm, bet arī visplašākajā starptautiskajā līmenī.

Transnacionālās kriminālās struktūras izmanto tiesiskās regulācijas nepilnības, starptautiskās tiesiskās sadarbības sadrumstalotību un fragmentārismu, kā arī jaunas metodes un paṇēmienus noziedzīgo aktivitāšu îstenošanā, tostarp tīklveida darbības moduḷus. Transnacionālā organizētā noziedzība ir drauds globālajai drošîbai, un tā var nodarīt ievērojamu sociālu un ekonomisku kaitējumu sabiedrībai. Lai nepiel̦autu organizēto kriminālo grupējumu ietekmes palielināšanos, ir jāizstrādā un jārealizē papildu pasākumi, kuri būtu balstîti uz globalizācijas priekšrocībām un ietvertu jaunas informatīvās un komunikatīvās tehnoloǵijas.

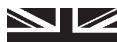 \\ Transnational Organised Criminal Groups in International Criminal Network Structure Context}

\section{Abstract}

Transnational organised crime is a major threat to global security and can cause significant social and economic damage. Prevention efforts need to be increased in order to encompass this phenomenon. Transnational organised crime benefits from certain legal loopholes, and law enforcement agencies have a difficulty in reacting quickly to criminal businesses which use very sophisticated methods to conceal their activities and the proceeds of their crimes, and take advantage of globalisation and the use of information and communication technologies. Through pyramidal structures, transnational organised crime has evolved to networks of cells with continuously changing partners and even locations. As organised criminals take advantage of the advances in ICTs and become ever defter in their methods, and with law enforcement authorities increasingly in need of additional resources, administrative synergies emerge as a natural and cost-efficient extension of the powers that counter organised crime.

Keywords: globalisation, criminological research, transnational crime, international criminal networks, transnational organised group. 
Andrejs Vilks. Transnacionālās organizētās noziedzīgās grupas starptautisko kriminālo tīkla struktūru kontekstā

\section{Literatūra}

1. White Paper on Transnational Organised Crime. European Comimittee on Crime. Strasbourg, 6 October 2014. Iegūts no: http://www.coe.int/t/dghl/standardsetting/pc-oc/PCOC_documents/Documents\%202014/CDPC\%20(2014)\%2011\%20Fin\%20-\%20e\%20-\%20White\%20 paper.pdf

2. http://www.walkfree.org/

3. Holmes, K. In the Future, Your Drug Dealer Will Be a Printer. July 4, 2012. Iegūts no: http:// www.vice.com/read/in-the-future-your-drug-dealer-will-be-a-printer [sk. 02.08.2015.].

4. Global Organized Crime Bigger Than Indonesia's GDP: Australia. Iegūts no: http://jakartaglobe. beritasatu.com/international/global-organized-crime-bigger-than-indonesias-gdp-australia/

5. EU Serious and Organised Crime Threat Assessment (SOCTA 2013). Iegūts no: https:// www.europol.europa.eu/content/europol-identifies-3600-organised-crime-groups-active-eueuropol-report-warns-new-breed-crim

6. Современная мафия вкмадывает Аеньги в мегальные компании, расширяя спектр преступной деятельности. Iegūts no: https://russian.rt.com/article/53915

7. Par organizētās noziedzības novēršanas un apkarošanas plānu 2014.-2016. gadam. Ministru kabineta noteikumi Nr. 214 no 2014. gada 5. jūnija. Iegūts no: http://likumi.lv/doc. php?id=266722

8. В этом году в $\Lambda$ атвии задержано 25 организованных преступных группировок. Iegūts no: http://www.mixnews.lv/ru/incidents/news/2015-09-23/185210

9. Lampe, K. von, Johansen, P. O. Criminal Networks and Trust. Iegūts no: http://www.organizedcrime.de/criminalnetworkstrust.htm

10. Arquilla, J., Ronfeldt, D., Zanini, M. Networks, Netwar and Information-Age Terrorism. RAND Corporation, 1999. P. 50.

11. Global Terrorism Index 2015. The Institute for Economics and Peace. Iegūts no: http://economicsandpeace.org/wp-content/uploads/2015/11/Global-Terrorism-Index-2015.pdf

12. Stilwell, B. Sex, drugs, and Bitcoin: The 10 ways ISIS pays the bills. Iegūts no: http://www.wearethemighty.com/lists/10-ways-isis-pays-bills 